medRxiv preprint doi: https://doi.org/10.1101/2021.08.06.21261711; this version posted August 7, 2021. The copyright holder for this preprint (which was not certified by peer review) is the author/funder, who has granted medRxiv a license to display the preprint in All rights reserved. No reuse allowed without permission.

\title{
Preterm birth rates during the COVID-19 lockdown in Queensland Australia
}

Authors: Brittany Jasper ${ }^{1,2,3}$, Tereza Stillerova ${ }^{1,3}$, Christopher Anstey ${ }^{1,4}$, Edward Weaver ${ }^{1,2,4}$

Affiliations: ${ }^{1}$ School of Medicine, Griffith University, Queensland, Australia, ${ }^{2}$ North West Anglia Healthcare NHS Trust, Cambridgeshire, United Kingdom, ${ }^{3}$ Department of Obstetrics and Gynaecology, Sunshine Coast University Hospital, Queensland, Australia, ${ }^{4}$ Faculty of Medicine, University of Queensland, Queensland, Australia.

Corresponding author: Brittany Jasper, School of Medicine, Griffith University, 6 Doherty Street, Birtinya, 4575, Queensland, Australia, email: brittanyjasper@mail.com

\section{All authors:}

Tereza Stillerova

Obstetrics and Gynaecology, Sunshine Coast University Hospital, Birtinya, Queensland, Australia

Christopher Anstey

School of Medicine, Griffith University (Sunshine Coast Campus), Queensland, Australia

Edward Weaver

Obstetrics and Gynaecology, Sunshine Coast University Hospital, Birtinya, Queensland, Australia

Word count: 2495 words

Keywords: preterm birth, prematurity, stillbirth, COVID, coronavirus, pandemic, lockdown 
medRxiv preprint doi: https://doi.org/10.1101/2021.08.06.21261711; this version posted August 7, 2021. The copyright holder for this preprint (which was not certified by peer review) is the author/funder, who has granted medRxiv a license to display the preprint in All rights reserved. No reuse allowed without permission.

\section{ABSTRACT \\ Background}

Preventative strategies for preterm birth are lacking. Recent evidence proposed COVID-19 lockdowns may have contributed to changes in preterm birth. We aimed to determine the prevalence of preterm birth during the COVID-19 lockdown on the Sunshine Coast and in the state of Queensland, Australia.

\section{Methods}

Retrospective cohort analysis of all births in Queensland including the Sunshine Coast University Hospital, during two epochs, April 1-May 31, 2020 (lockdown) and June 1-July 31, 2020 (postlockdown), compared to antecedent calendar-matched periods in 2018-2019. Prevalence of preterm birth, stillbirth, and late terminations were examined.

\section{Results}

There were 64,989 births in Queensland from April to July 2018-2020. At the Sunshine Coast University Hospital, there was a significantly higher chance of birth at term during both lockdown (OR 1.81, 95\% $\mathrm{Cl} 1.17,2.79 ; \mathrm{P}=0.007)$ and post-lockdown $(\mathrm{OR} 2.01,95 \% \mathrm{Cl}$ 1.27, 3.18; $\mathrm{P}=0.003)$. At the same centre, prevalence of preterm birth was 5.5\% (30/547) during lockdown, compared to $9.1 \%(100 / 1095)$ in previous years, a $40.0 \%$ relative reduction $(P=0.016)$. At this centre during lockdown, emergency caesareans concurrently decreased $(P=0.034)$ and vacuum-assisted births increased $(P=0.036)$. In Queensland overall, there was a nonsignificant decrease in the prevalence of preterm birth during lockdown.

\section{Conclusions}

There is a link between lockdown and a reduction in the prevalence of preterm birth on the Sunshine Coast. The cause is speculative. Further research is needed to determine a causal link and assess if this can be translated into management which provides a sustained reduction in preterm birth and its associated morbidity and mortality. 
medRxiv preprint doi: https://doi.org/10.1101/2021.08.06.21261711; this version posted August 7, 2021. The copyright holder for this preprint (which was not certified by peer review) is the author/funder, who has granted medRxiv a license to display the preprint in All rights reserved. No reuse allowed without permission.

\section{MAIN RESEARCH ARTICLE}

\section{INTRODUCTION}

Preterm birth (PTB) is a major problem worldwide and is the leading cause of death in children under five.[1] Despite advances in perinatal care, there has been no sustained reduction in the prevalence of PTB and preventative measures remain only partially successful.[2]

The World Health Organisation (WHO) declared COVID-19 a pandemic on 11 March, 2020.[3] This was followed by lockdowns across the globe, causing unprecedented effects on society and human behaviour in ways not seen before. In Queensland, Australia, the restrictions to mitigate the spread of COVID-19 culminated in a nine-week state-wide lockdown from March 30 to June 1, 2020, with a phased easing of restrictions.[4] During lockdown, all shops, restaurants, schools, universities, and nonessential workplaces were closed.[4-5] Residents were prohibited from leaving their homes except for essential reasons (Figure 1).[4]

To minimise the risk of virus transmission, models of antenatal care at the Sunshine Coast University Hospital (SCUH) were adapted.[6] Women were risk-triaged by senior obstetric staff to either virtual or in-person appointments utilising COVID-19 safe practices.[6]

In the wake of the pandemic, research emerged demonstrating the varied impact of lockdown on the prevalence of PTB worldwide.[7-16] We aimed to determine the prevalence of PTB during the COVID19 lockdown on the Sunshine Coast and in the state of Queensland, Australia. 
medRxiv preprint doi: https://doi.org/10.1101/2021.08.06.21261711; this version posted August 7, 2021. The copyright holder for this preprint (which was not certified by peer review) is the author/funder, who has granted medRxiv a license to display the preprint in All rights reserved. No reuse allowed without permission.

\section{METHODS}

\section{Study population}

This study focused on pregnant women in two geographical locations in Australia. Firstly, the state of Queensland, which services the health needs of over 5 million people, and secondly, SCUH, a health service which provides care for the 400,000 people living in this area of Queensland.[17-18] Of pregnant women in Queensland, 6.8\% reside in the SCUH catchment.[19] Three percent of pregnant women in Queensland were aged less than 20 years and four percent were aged over 40 years[19], 7.5\% identified as Aboriginal or Torres Strait Islander[19], 21.0\% were obese at the time of conception[20], and $11 \%$ smoked during pregnancy[20].

\section{Ethics approval and data collection}

This study was reviewed by the Prince Charles Hospital Human Research Ethics Committee and approval was granted as a low or negligible risk project (Project ID 70040; November 3, 2020). Data pertaining to SCUH was collected from the health service birth registry. Queensland state-wide data was sourced from The Perinatal Data Collection, Department of Health.

\section{Study design}

Retrospective cohort analysis of all births in Queensland, Australia was carried out during two epochs, April 1-May 31, 2020 (lockdown) and June 1-July 31, 2020 (post-lockdown), compared to antecedent calendar-matched periods from the preceding two years 2018-2019. The prevalence of PTB, stillbirth, and late terminations were examined. Inclusion criteria were all births after 20 weeks' gestation (live and still) and late terminations. All PTB defined as less than 37 weeks' gestation were analysed, including sub-group analyses of extreme preterm $(20+0-27+6$ weeks' gestation), very preterm $(28+0-$ $31+6$ weeks' gestation), and moderate to late preterm $(32+0-36+6$ weeks' gestation). To facilitate comparison of birth data at SCUH to the state of Queensland overall, and to wholly represent all births after 20 weeks' gestation, no births were excluded because of multiple births, stillbirths after 20 weeks' gestation, or terminations after 20 weeks' gestation. At SCUH, perinatal characteristics were collected, including maternal age, body mass index (BMI), parity, mode of delivery, and infant sex. Further analysis of PTB data at SCUH was carried out to examine the proposed aetiology of PTB and birth outcomes including spontaneous live PTB, iatrogenic live PTB, stillbirth after 20 weeks' gestation, and 
medRxiv preprint doi: https://doi.org/10.1101/2021.08.06.21261711; this version posted August 7, 2021. The copyright holder for this preprint (which was not certified by peer review) is the author/funder, who has granted medRxiv a license to display the preprint in

All rights reserved. No reuse allowed without permission.

late termination after 20 weeks' gestation. We subclassified spontaneous live PTB aetiologies into preterm premature rupture of membranes, preterm labour and birth, and multiple pregnancy. Subclassifications for iatrogenic (medically indicated) live PTB included intrauterine growth restriction, hypertension (including pre-eclampsia and HELLP syndrome (haemolysis, elevated liver enzymes, low platelet count)), multiple pregnancy, fetal distress, placental abruption and antepartum haemorrhage, and other maternal comorbidities.

\section{Statistical analysis}

All data was anonymised and deidentified prior to analysis. Univariate logistic regression was performed to identify potential predictors of preterm or term birth. All variables with $P<0.20$ were included in multivariate logistic regression analysis. The prevalence of PTB, stillbirth, and late terminations were calculated. Percent change was calculated to assess for any difference in prevalence between time periods. Descriptive statistics were reported as mean and standard deviation (SD) for normally distributed continuous data, median and interquartile range (IQR) for non-normally distributed data, and frequencies and percentages for categorical data. Continuous data were tested for normality using the Shapiro-Wilk test and analysed using the t-test. Categorical data were analysed using either a MannWhitney U-test, Chi-squared, or Fisher's exact test, where appropriate. P-values $<0.05$ were considered significant. All analyses were conducted using $\mathrm{R}$ statistical software.

\section{Patient and public involvement}

Patient and public involvement began in the early stages of project planning. The Preterm Infants Parents Association (PIPA) is a registered Australian charity and support network for families with premature babies.[21] The PIPA team reviewed the proposed study design, research questions, and confirmed all data collection processes were confidential. Once the study is published, a plain language summary will be distributed to the PIPA database of preterm infants' parents and their network. 
medRxiv preprint doi: https://doi.org/10.1101/2021.08.06.21261711; this version posted August 7, 2021. The copyright holder for this preprint (which was not certified by peer review) is the author/funder, who has granted medRxiv a license to display the preprint in All rights reserved. No reuse allowed without permission.

\section{RESULTS}

There were 64,989 births in the state of Queensland, Australia, including 3,296 births at SCUH between April 1-July 31, 2018-2020. Univariate logistic regression of births at SCUH revealed maternal age, BMI, parity, and infant sex were all nonsignificant predictors of PTB. Multivariate logistic regression of births at SCUH demonstrated a significantly higher chance of birth at term during both the lockdown period April-May 2020 (OR 1.81, 95\% Cl 1.17, 2.79; P=0.007) and the post-lockdown period June-July 2020 (OR 2.01, 95\% Cl 1.27, 3.18; P=0.003), when compared with antecedent calendar-matched periods in 2018-2019 (supplementary material).

All births at SCUH and in the state of Queensland overall are summarised in table 1. During lockdown, the prevalence of PTB at SCUH was 5.5\% (30/547), compared to $9.1 \%(100 / 1095)$ during the same period in previous years, representing a $40.0 \%$ relative reduction in PTB $(P=0.016)$. This reduction in PTB at SCUH appeared to be driven by moderate to late PTB $(32+0-36+6$ weeks'). The prevalence of moderate to late PTB was $4.6 \%$ (25/547) during lockdown compared to $7.5 \%(82 / 1095)$ in previous years, a $39.0 \%$ relative reduction $(\mathrm{P}=0.034)$. In contrast, the prevalence of PTB in the state of Queensland overall was $8.6 \%(870 / 10154)$ during lockdown compared to $8.9 \%(1871 / 20939)$ in previous years, a nonsignificant $4.1 \%$ relative reduction in PTB $(\mathrm{P}=0.33)$.

After lockdown restrictions eased, the prevalence of PTB at SCUH was 5.0\% (26/524) during the postlockdown period compared to $7.1 \%(80 / 1130)$ in previous years, a nonsignificant $29.9 \%$ relative reduction in PTB $(P=0.12)$. This decrease appeared to be driven by moderate to late $P T B$, as the prevalence in this group was $3.8 \%(20 / 524)$ during post-lockdown, compared to $6.4 \%(72 / 1130)$ in previous years, a $40.0 \%$ relative reduction in moderate to late PTB post-lockdown ( $P=0.045)$. In the state of Queensland overall, there was no significant difference in PTB observed in the post-lockdown period compared to previous years.

Table 2 outlines the perinatal characteristics of births at SCUH between April 1-July 31, 2018 to 2020. Most pregnant women were aged $20-40$ years and only $4.3 \%$ of women were in the higher risk age groups for PTB of $\leq 20$ years or $\geq 40$ years.[22] There was a general increase in BMI in both the lockdown and post-lockdown groups in 2020 when compared to 2018-2019, consistent with the rising prevalence 
medRxiv preprint doi: https://doi.org/10.1101/2021.08.06.21261711; this version posted August 7, 2021. The copyright holder for this preprint (which was not certified by peer review) is the author/funder, who has granted medRxiv a license to display the preprint in perpetuity.

All rights reserved. No reuse allowed without permission.

of obesity.[6] At SCUH during lockdown, we observed a $29.4 \%$ relative decrease in emergency caesarean sections (in labour) and concurrent $41.7 \%$ relative increase in vacuum-assisted births when compared to previous years $(\mathrm{P}=0.034, \mathrm{P}=0.036$, respectively).

Upon further analysis of PTB data at SCUH, no significant change was identified in either spontaneous or iatrogenic (medically indicated) live PTB during lockdown or post-lockdown (table 3). A nonsignificant increase in stillbirth was observed during lockdown and post-lockdown when compared to previous years at $\mathrm{SCUH}$, although the numbers were very low $(\mathrm{P}=0.09, \mathrm{P}=0.08$, respectively). There was no change in the prevalence of late terminations, compared to previous years at SCUH. 
medRxiv preprint doi: https://doi.org/10.1101/2021.08.06.21261711; this version posted August 7, 2021. The copyright holder for this preprint (which was not certified by peer review) is the author/funder, who has granted medRxiv a license to display the preprint in

All rights reserved. No reuse allowed without permission.

\section{DISCUSSION}

Australia enforced strict lockdowns to mitigate the spread of COVID-19, reaching a stringency level of 71.3 in a 1 to 100 scale on the Oxford Government Response Tracker.[23] Residents were not permitted to leave their home except for essential reasons.[4] At the Sunshine Coast University Hospital (SCUH) in Queensland Australia, there was a significantly higher chance of birth at term during both the lockdown and post-lockdown periods, when compared to previous years. During lockdown, a $40.0 \%$ relative reduction in the prevalence of PTB was observed at SCUH (table 1). This finding is consistent with similar studies worldwide which reported a significantly lower prevalence of PTB during lockdown.[7,9,10,13,14] In contrast to the reduction in PTB observed at SCUH, there was a nonsignificant decrease in PTB observed in the state of Queensland overall during lockdown. On the Sunshine Coast and in Brisbane[9], both cities in Queensland, there was a reduction in PTB, however in our study, this reduction was not observed for the state overall. It is possible that the effect of lockdown on PTB was more apparent in cities, although this requires further investigation. At SCUH, the reduction in the prevalence of PTB during lockdown was driven by moderate to late PTB, in line with similar evidence from Australia.[9] This reduction in moderate to late PTB was sustained during the post-lockdown period, suggesting the possibility that altered maternal behaviours enforced during lockdown may have persisted even after restrictions were lifted.

The obstetric antecedents of PTB include delivery for materno-fetal indications (iatrogenic), spontaneous preterm labour and birth, or preterm premature rupture of membranes.[22] In high-income countries such as Australia, 30\% of PTB are iatrogenic, while $70 \%$ are spontaneous.[2] The aetiology of most spontaneous PTB is unknown, although in singleton pregnancies the most common cause is likely intrauterine inflammation and placental anomalies.[2] We did not observe a significant difference in the prevalence of spontaneous or iatrogenic live PTB during lockdown or post-lockdown, compared to previous years. However, other studies from Australia[9] and Israel[15] reported a reduction in iatrogenic PTB during lockdown.

Although differences were observed in the prevalence of PTB, the cause for this is speculative. During lockdown, maternal behaviours were changed as a result of lockdown and public health messaging, and women likely had increased health awareness. During lockdown, Australia noted improved air 
medRxiv preprint doi: https://doi.org/10.1101/2021.08.06.21261711; this version posted August 7, 2021. The copyright holder for this preprint (which was not certified by peer review) is the author/funder, who has granted medRxiv a license to display the preprint in All rights reserved. No reuse allowed without permission.

quality[24], which is known to impact PTB.[25] Although the causality between PTB and work remains controversial, with more women working from home or not working, there may have been more time for sleep, exercise, and healthy eating.[16] However, it is important to recognise the known negative impacts of lockdown for some women, as there was a rise in domestic violence and poor mental health in Australia during lockdown.[26-27]

When postulating factors which may have contributed to the reduction in PTB, it is reasonable to consider a decrease in the transmission of infections, such as influenza, a known risk factor for PTB.[2829] Pregnant women have an increased risk of severe influenza, and severe infection increases the risk of PTB and stillbirth.[28-29] It is recommended that pregnant women receive the influenza vaccine antenatally, which reduces the risk of influenza for the pregnant woman, the risk of PTB, and confers immunity to the newborn for three to six months.[29-30]

In Queensland, Australia, maternal influenza vaccination uptake has been suboptimal with $42.0 \%$ of women receiving the vaccine in 2018 , despite it being encouraged and free of charge.[20] In the context of COVID-19, the Australian government introduced measures to increase the uptake of influenza vaccination and emphasised the importance of pregnant women receiving the vaccine.[31-32] The time to immunity after influenza vaccination is approximately 2 weeks.[33] Influenza vaccination uptake in Australia increased from 3.5 million in 2018 to 7.3 million doses by May 2020 during lockdown, which may be attributed to effective public health messaging and increased health awareness during the pandemic.[34] In 2020, Australia noted the lowest rates of influenza in the past decade, almost 8 times lower than the five-year average[35], likely as a result of exceptionally high vaccination uptake and reduced transmission of infections during lockdown. Both high influenza vaccination uptake and low influenza infection rates may have contributed to the reduction observed in PTB, although this requires further study.

During the lockdown period at SCUH, there was a $29.4 \%$ relative decrease in emergency caesarean sections and concurrent $41.7 \%$ relative increase in vacuum-assisted vaginal births (table 2). This trend did not extend into the post-lockdown period. It is possible that reduced caesarean sections during lockdown were due to protracted COVID-related infection control policies, potential altered staff levels 
medRxiv preprint doi: https://doi.org/10.1101/2021.08.06.21261711; this version posted August 7, 2021. The copyright holder for this preprint (which was not certified by peer review) is the author/funder, who has granted medRxiv a license to display the preprint in All rights reserved. No reuse allowed without permission.

with some staff affected by or shielding from COVID, or other factors not yet delineated. A similar study from Japan demonstrated a comparable reduction in caesarean sections during the lockdown.[13] However, a British study[11] showed no change, and an Indian study[12] showed an increase in caesarean sections during lockdown. Further research into provision of maternity care during the lockdown was beyond the scope of this study.

At SCUH, there was a nonsignificant increase in stillbirth during lockdown and post-lockdown (table 3). Other studies demonstrated a wide variation in stillbirth rates during lockdown; studies from Australia[9,14], England[36-37], and Israel[15] showed no change in stillbirth, while other studies from England[11], India[12], and Italy[8] demonstrated an increase in stillbirth rates during lockdown. This conflicting evidence underscores the need for ongoing research into stillbirth during the COVID-19 pandemic.

To our knowledge, our study is the first to examine state-wide PTB data during the COVID-19 pandemic in Australia. This allowed for comparison of one health region to a large state overall, including metropolitan, regional, and rural areas. This paper is one of only three studies from Australia to investigate the prevalence of PTB during the pandemic. For births at SCUH, we analysed perinatal characteristics including maternal demographics, mode of delivery, maternal comorbidities, and birth outcomes such as spontaneous live PTB, iatrogenic live PTB, stillbirth, and late terminations.

Our study has limitations, which should be considered when interpreting results. As this study was observational, it was not possible to account for unmeasured confounding variables. Although detailed data was collected on all births at SCUH, state-wide data for Queensland was limited to birth outcomes and gestational age, as per the predetermined perinatal data collection format. As our health service opened a new tertiary hospital in April 2017 (SCUH), retrospective analysis was only completed for two years prior from 2018-2019. We acknowledge that longer retrospective analysis would be preferable to further compare year-by-year variations in birth outcomes.

Further research is required from ethnically, geographically, and socioeconomically diverse regions and high-risk groups for PTB such as Aboriginal and Torres Strait Islander women in Australia. Qualitative 
medRxiv preprint doi: https://doi.org/10.1101/2021.08.06.21261711; this version posted August 7, 2021. The copyright holder for this preprint (which was not certified by peer review) is the author/funder, who has granted medRxiv a license to display the preprint in perpetuity.

All rights reserved. No reuse allowed without permission.

analysis of maternal behaviours during lockdown was beyond the scope of this study but would be highly informative.

\section{Conclusion}

There is a link between lockdown and a reduction in the prevalence of PTB on the Sunshine Coast.

The cause is speculative at present. Further research is needed to determine a causal link and assess if this can be translated into management which provides a sustained reduction in PTB and its associated morbidity and mortality. 
medRxiv preprint doi: https://doi.org/10.1101/2021.08.06.21261711; this version posted August 7, 2021. The copyright holder for this preprint (which was not certified by peer review) is the author/funder, who has granted medRxiv a license to display the preprint in All rights reserved. No reuse allowed without permission.

Acknowledgements: The authors would like to acknowledge the Gubbi Gubbi people, the traditional owners of the land on the Sunshine Coast, and pay respect to Elders past, present, and emerging. We thank our obstetric, midwifery, neonatal, and administrative colleagues at SCUH who supported this project, particularly Carol Newell, Nikki Doogue, Tracy Kerr, and Tammy Doyle for collation of obstetric data. The Perinatal Data Collection, Queensland Department of Health are acknowledged state-wide data collection. We acknowledge the Queensland Facility for Advanced Bioinformatics, Nicholas Matigan for assistance with statistical analyses and Nicholas Snels for his comments. PIPA and Eileen Cooke are gratefully acknowledged for their independent review of our study design.

Contributors: BJ, TS, EW conceptualised and designed the study. BJ and TS obtained and analysed the initial data. BJ, TS, CA, EW analysed the final data. BJ and TS drafted the initial manuscript. BJ, TS, CA, EW critically reviewed and revised the final manuscript. EW supervised the research project. All authors approved the final manuscript as submitted. All authors listed meet authorship criteria.

Funding: The authors did not receive any funding or financial sponsorship to carry out this research.

Competing interests: None declared.

Ethics approval: As per the National Health and Medical Research Council of Australia (NHMRC), this study was reviewed by The Prince Charles Hospital Human Research Ethics Committee and approval was granted as a low or negligible risk project (Project ID 70040; November 3, 2020).

Disclaimer: The views and postulations expressed in this paper are those of the authors, and are not representative of any employing agencies such as the Sunshine Coast University Hospital, Griffith University, the University of Queensland, North West Anglia Healthcare NHS Trust, The Perinatal Data Collection, Queensland Government, Department of Health, or the Preterm Infants Parents Association.

Data availability statement: The authors confirm that the data supporting the findings of this study are available within the article and its supplementary materials.

Patient and public involvement: A public group (PIPA) were consulted in this study, see methods. 
medRxiv preprint doi: https://doi.org/10.1101/2021.08.06.21261711; this version posted August 7, 2021. The copyright holder for this preprint (which was not certified by peer review) is the author/funder, who has granted medRxiv a license to display the preprint in All rights reserved. No reuse allowed without permission.

\section{What is already known on this topic}

- In light of the COVID-19 pandemic, international research has demonstrated conflicting evidence regarding the effect of lockdown on the prevalence of preterm birth (PTB).[7-16]

- In Australia, PTB is associated with multiple pregnancy, tobacco smoking, living in remote areas, indigenous mothers, and mothers aged $\leq 20$ years or $\geq 40$ years.[38]

- PTB is the leading cause of death in children under five[1], and the prevalence in Australia has remained largely static, despite perinatal care advances.[2]

\section{What this study adds}

- During the COVID-19 lockdown and post-lockdown periods, the prevalence of moderate to late PTB decreased at the Sunshine Coast University Hospital in Queensland, Australia.

- Decreased transmission of infections[35], increased influenza vaccination rates[34], and improved air quality[24] may have been favourable in reducing PTB during the COVID-19 lockdown.

- This study highlights the need for further research into factors which may have contributed to the reduction in PTB observed during the pandemic. 
medRxiv preprint doi: https://doi.org/10.1101/2021.08.06.21261711; this version posted August 7, 2021. The copyright holder for this preprint (which was not certified by peer review) is the author/funder, who has granted medRxiv a license to display the preprint in All rights reserved. No reuse allowed without permission.

\section{TABLE AND FIGURE CAPTION LIST}

Table 1. Birth outcomes during the lockdown and post-lockdown periods from 2018-2020 at the Sunshine Coast University Hospital and in the state of Queensland overall.

Table 2. Perinatal characteristics at the Sunshine Coast University Hospital from 2018-2020.

Table 3. Birth outcomes and proposed aetiologies for preterm birth during the lockdown and postlockdown periods from 2018-2020 at the Sunshine Coast University Hospital.

Figure 1. Timeline of COVID-19 restriction implementation in Queensland, Australia.[4]

Supplementary table 1. Univariate analysis: logistic regression using term ( $0=$ preterm, $1=$ term) as the dependent (outcome) variable at the Sunshine Coast University Hospital from 2018-2020.

Supplementary table 2. Multivariate analysis: logistic regression using term ( $0=$ preterm, $1=$ term) as the dependent (outcome) variable at the Sunshine Coast University Hospital from 2018-2020. 
medRxiv preprint doi: https://doi.org/10.1101/2021.08.06.21261711; this version posted August 7, 2021. The copyright holder for this preprint (which was not certified by peer review) is the author/funder, who has granted medRxiv a license to display the preprint in All rights reserved. No reuse allowed without permission.

\section{REFERENCE LIST}

1. Levels and trends in child mortality: report 2017, Estimates developed by the UN inter-agency group for child mortality estimation [Internet]. New York: United Nations Children's Fund; 2017 [cited Nov 16, 2020]. Available from:

https://reliefweb.int/sites/reliefweb.int/files/resources/Child_Mortality_Report_2017.pdf

2. Keelan JA and Newnham JP. Recent advances in the prevention of preterm birth. F1000Res 2017;6(F1000 Faculty Rev):1139. doi:10.12688/f1000research.11385.1

3. World Health Organisation. WHO News: Timeline of WHO's response to COVID-19 [Internet]. Geneva: WHO; June 29, 2020 [cited Oct 9, 2020]. Available from: www.who.int/news/item/2906-2020-covidtimeline

4. The Australian Broadcasting Corporation. Queensland's coronavirus timeline: how COVID-19 cases spread around the state [Internet]. Sydney: ABC News; September 25, 2020 [cited Oct 9, 2020]. Available from: www.abc.net.au/news/2020-03-28/coronavirus-timeline-queenslandtracking-spread/12077602?nw=0

5. The Australian Broadcasting Corporation. Queenslanders enjoy pre-pandemic freedoms as state eases to stage three coronavirus restrictions [Internet]. Sydney: ABC news; July 3, 2020 [cited Jul 8, 2020]. Available from: https://www.abc.net.au/news/2020-07-03/queenslandcoronavirus-restrictions-lift-to-prepandemic-time/12420954

6. Queensland Clinical Guidelines Maternity care for mothers and babies during the COVID-19 pandemic. Guideline No. MN20.63-V5-R25. Brisbane: Queensland Health; March 26, 2020. [cited Jul 8, 2020]. Available from: https://www.health.qld.gov.au/_data/assets/pdf_file/0033/947148/g-covid-19.pdf

7. Been JV, Ochoa LB, Bertens LCM, et al. Impact of COVID-19 mitigation measures on the incidence of preterm birth: a national quasi-experimental study. Lancet Public Health 2020;5:e604-611. doi:10.1016/S2468-2667(20)30223-1

8. De Curtis M, Villani L, Polo A. Increase of stillbirth and decrease of late preterm infants during the COVID-19 pandemic lockdown. Arch Dis Child Fetal Neonatal Ed 2021;106(4):456. doi:10.1136/archdischild-2020-320682 
medRxiv preprint doi: https://doi.org/10.1101/2021.08.06.21261711; this version posted August 7, 2021. The copyright holder for this preprint (which was not certified by peer review) is the author/funder, who has granted medRxiv a license to display the preprint in All rights reserved. No reuse allowed without permission.

9. Gallo LA, Gallo TF, Borg DJ, et al. A decline in planned, but not spontaneous, preterm birth rates in a large Australian tertiary maternity centre during COVID-19 mitigation measures. Aust N Z J Obstet Gynaecol. Published online first: July 12, 2021. doi:10.1111/ajo.13406

10. Hedermann G, Hedley PL, Bækvad-Hansen M, et al. Danish premature birth rates during the COVID-19 lockdown. Arch Dis Child Fetal Neonatal Ed 2021;106(1):93-95. doi:10.1136/archdischild-2020-319990

11. Khalil A, von Dadelszen P, Draycott $T$, et al. Change in the Incidence of Stillbirth and Preterm Delivery During the COVID-19 Pandemic. JAMA 2020;324(7):705-706. doi:10.1001/jama.2020.12746

12. Kumari V, Mehta K, Choudhary R. COVID-19 outbreak and decreased hospitalisation of pregnant women in labour. Lancet Glob Health 2020;8(9):e1116-e1117. doi:10.1016/S2214$109 \times(20) 30319-3$

13. Maeda $\mathrm{Y}$, Nakamura $\mathrm{M}$, Ninomiya $\mathrm{H}$, et al. Trends in intensive neonatal care during the COVID-19 outbreak in Japan. Arch Dis Child Fetal Neonatal Ed 2021;106:F327-329. doi:10.1136/archdischild-2020-320521

14. Matheson A, McGannon CJ, Malhotra A, et al. Prematurity Rates During the Coronavirus Disease 2019 (COVID-19) Pandemic Lockdown in Melbourne, Australia. Obstet Gynecol 2021;137(3):405-407. doi:10.1097/AOG.0000000000004236

15. Meyer R, Bart $\mathrm{Y}$, Tsur A, et al. A marked decrease in preterm deliveries during the coronavirus disease 2019 pandemic. Am J Obstet Gynaecol 2021;224(2):234-237. doi:10.1016/j.ajog.2020.10.017

16. Philip RK, Purtill H, Reidy E, et al. Unprecedented reduction in births of very low birthweight (VLBW) and extremely low birthweight (ELBW) infants during the COVID-19 lockdown in Ireland: a 'natural experiment' allowing analysis of data from the prior two decades. BMJ Glob Health 2020;5:e003075. doi:10.1136/bmjgh-2020-003075

17. Chief Health Officer Queensland. Population Health Status Profile Queensland [Internet]. Brisbane: Queensland Government; 2020 [cited Jul 8, 2021]. Available from: https://public.tableau.com/views/populationprofile/Page1?\%3Aembed=y\&\%3Adisplay=no\&\%3 AshowShareOptions=false \&\%3AshowVizHome=no\&fbclid=IwAR2FCu1fRd0xSKshhsispkxxjf eWjyNqbYvljOKstm_ZPYkIITrE8gqMr5Y 
medRxiv preprint doi: https://doi.org/10.1101/2021.08.06.21261711; this version posted August 7, 2021. The copyright holder for this preprint (which was not certified by peer review) is the author/funder, who has granted medRxiv a license to display the preprint in All rights reserved. No reuse allowed without permission.

18. Chief Health Officer Queensland. Population Health Status Profile Sunshine Coast HHS [Internet]. Brisbane: Queensland Government; 2020 [cited Jul 8, 2021]. Available from: https://public.tableau.com/views/populationprofile/Page1?\%3Aembed=y\&\%3Adisplay=no\&\%3 AshowShareOptions=false \&\%3AshowVizHome=no\&fbclid=IwAR2FCu1fRd0xSKshhsispkxxjf eWjyNqbYvljOKstm_ZPYkIITrE8gqMr5Y

19. Queensland Health. Perinatal data collection 2019 [Internet]. Brisbane: Queensland Government; December, 2020. [cited Jul 9, 2021]. Available from: https://www.health.qld.gov.au/_data/assets/pdf_file/0027/1004958/4-demgrph2019.pdf

20. Queensland Government, Queensland Health. The health of Queenslanders 2020: Report of the Chief Health Officer Queensland [Internet]. Brisbane: Queensland Health; November, 2020 [cited Dec 15, 2020]. Available from: https://www.health.qld.gov.au/_data/assets/pdf_file/0019/1011286/cho-report-2020-full.pdf

21. Preterm Infants' Parents' Association. Preterm Infants' Parents' Association [Internet]. Brisbane: Preterm Infants' Parents' Association; 2020 [cited Jul 12, 2021]. Available from: https://www.pipa.org.au/

22. Goldenberg RL, Culhane JF, Lams JD, et al. Epidemiology and causes of preterm birth. Lancet 2008;371(9606):75-84. doi:10.1016/S0140-6736(08)60074-4

23. Hale T, Angrist N, Cameron-Blake E, et al. A global panel database of pandemic policies (Oxford COVID-19 Government Response Tracker). Nat Hum Behav 2021;5(4):529-538. doi:10.1038/s41562-021-01079-8

24. Duc H, Salter D, Azzi M, et al. The Effect of Lockdown Period during the COVID-19 Pandemic on Air Quality in Sydney Region, Australia. Int J Environ Res Public Health 2021;18(7):3528. doi:10.3390/ijerph18073528

25. Bekkar B, Pacheco S, Basu R, et al. Association of Air Pollution and Heat Exposure With Preterm Birth, Low Birth Weight, and Stillbirth in the US: A Systematic Review. JAMA Netw Open 2020;3(6):e208243. doi:10.1001/jamanetworkopen.2020.8243

26. Boxall H, Morgan A, Brown R. The prevalence of domestic violence among women during the COVID-19 pandemic [Internet]. Canberra: Australian Institute of Criminology; June, 2020 [cited May 12, 2021]. Available from: https://www.aic.gov.au/sites/default/files/202007/sb28_prevalence_of_domestic_violence_among_women_during_covid-19_pandemic.pdf 
medRxiv preprint doi: https://doi.org/10.1101/2021.08.06.21261711; this version posted August 7, 2021. The copyright holder for this preprint (which was not certified by peer review) is the author/funder, who has granted medRxiv a license to display the preprint in All rights reserved. No reuse allowed without permission.

27. Fisher JR, Tran TD, Hammarberg K, et al. Mental health of people in Australia in the first month of COVID-19 restrictions: a national survey. Med J Aust 2020;213(10):458-464. doi:10.5694/mja2.50831

28. Fell DB, Savitz DA, Kramer MS, et al. Maternal influenza and birth outcomes: systematic review of comparative studies. BJOG 2017;124:48-59. doi:10.1111/1471-0528.14143

29. Buchy P, Badur S, Kassianos G, et al. Vaccinating pregnant women against influenza needs to be a priority for all countries: An expert commentary. Int $J$ Infect Dis 2020;92:1-12. doi:10.1016/j.ijid.2019.12.019

30. Australian Government, Department of Health. Australian Immunisation Handbook: Influenza (Flu) [Internet]. Canberra: Department of Health; April 9, 2020 [cited Sep 6, 2020]. Available from: https://immunisationhandbook.health.gov.au/vaccine-preventable-diseases/influenza-flu

31. Australian Government, Department of Health. Clinical update: 2020 seasonal influenza vaccines - early advice for vaccination providers [Internet]. Canberra: Department of Health; March 2, 2020 [cited Mar 16, 2021]. Available from: https://www.health.gov.au/news/clinicalupdate-2020-seasonal-influenza-vaccines-early-advice-for-vaccination-providers

32. Richmond H, Rees N, McHale S, et al. Seasonal influenza vaccination during a pandemic. Hum Vaccin Immunother 2020;16(9):2219-2221. doi:10.1080/21645515.2020.1793713

33. Queensland Government, Queensland Health. Influenza vaccination guidelines. Brisbane: Queensland Health; March 23, 2021 [cited May 12, 2021]. Available from: https://www.health.qld.gov.au/clinical-practice/guidelines-procedures/diseasesinfection/immunisation/service-providers/influenza

34. Queensland Government, Department of Health, Minister Hunt. Record flu vaccines in 2020 to protect Australians [Internet]. Canberra: Department of Health; 27 May, 2020 [cited Sep 6, 2020]. Available from: https://www.health.gov.au/ministers/the-hon-greg-hunt$\mathrm{mp} / \mathrm{media} /$ record-flu-vaccines-in-2020-to-protect-australians\#: :text=27\%20May\%202020,An\%20additional\%20two\%20million\%20flu\%20vaccines\%20will\%20available\%20from\%20th is,flu\%20vaccines\%20provided\%20in\%202017

35. Australian Government, National Notifiable Disease Surveillance System. Number of notifications of Influenza (laboratory confirmed), Australia [Internet]. Canberra: Department of 
medRxiv preprint doi: https://doi.org/10.1101/2021.08.06.21261711; this version posted August 7, 2021. The copyright holder for this preprint (which was not certified by peer review) is the author/funder, who has granted medRxiv a license to display the preprint in perpetuity.

All rights reserved. No reuse allowed without permission.

Health; May 2021 [cited May 12, 2021]. Available from:

http://www9.health.gov.au/cda/source/rpt_3.cfm

36. Stowe J, Smith H, Thurland K, et al. Stillbirths During the COVID-19 Pandemic in England, April-June 2020. JAMA 2021;325(1):86-87. doi:10.1001/jama.2020.21369

37. Marques-Fernandez L, Sharma S, Mannu U, et al. Impact of Covid-19 on attendances for a 1st episode of reduced fetal movements: A retrospective observational study. PLoS One 2021;16(6):e0253796. doi:10.1371/journal.pone.0253796

38. Australian Institute of Health and Welfare. Australia's mothers and babies 2018: in brief [Internet]. Canberra, AlHW; 2020 [cited Nov 16, 2020]. Available from:

https://www.aihw.gov.au/getmedia/aa54e74a-bda7-4497-93ce-e0010cb66231/aihw-per108.pdf.aspx?inline=true 
medRxiv preprint doi: https://doi.org/10.1101/2021.08.06.21261711; this version posted August 7, 2021. The copyright holder for this preprint (which was not certified by peer review) is the author/funder, who has granted medRxiv a license to display the preprint in perpetuity.

All rights reserved. No reuse allowed without permission.

TABLES AND FIGURES

Table 1. Birth outcomes during the lockdown and post-lockdown periods from 2018-2020 at the Sunshine Coast University Hospital and in the state of Queensland overall.

\begin{tabular}{|c|c|c|c|c|c|c|}
\hline $\begin{array}{l}\text { Birth outcome } \\
\text { No./Total No. (\%) }\end{array}$ & $\begin{array}{l}\text { No lockdown } \\
\text { Apr-May 2018-9 } \\
(n=22 \text { 034) }\end{array}$ & $\begin{array}{l}\text { Lockdown } \\
\text { Apr-May } 2020 \\
(n=10701)\end{array}$ & $P$ & $\begin{array}{l}\text { No lockdown } \\
\text { Jun-Jul 2018-9 } \\
(n=21568)\end{array}$ & $\begin{array}{l}\text { Post-lockdown } \\
\text { Jun-Jul } 2020 \\
(n=10686)\end{array}$ & $P$ \\
\hline \multicolumn{7}{|c|}{ Total preterm births/Total births } \\
\hline $\mathrm{SCUH}^{\dagger}$ & $100 / 1095$ (9.13) & $30 / 547(5.48)$ & 0.016 & $80 / 1130(7.08)$ & $26 / 524(4.96)$ & 0.12 \\
\hline QLD $\ddagger$ & $1871 / 20939(8.94)$ & $870 / 10154(8.57)$ & 0.33 & $1865 / 20438(9.13)$ & $921 / 10162(9.06)$ & 0.87 \\
\hline \multicolumn{7}{|c|}{ Extreme preterm $(20+0-27+6)$} \\
\hline SCUH & $12 / 1095(1.10)$ & $3 / 547(0.55)$ & 0.41 & $5 / 1130(0.44)$ & $5 / 524(0.95)$ & 0.21 \\
\hline QLD & 193/20939 (0.92) & $113 / 10154(1.11)$ & 0.11 & $166 / 20438(0.81)$ & $87 / 10162(0.86)$ & 0.69 \\
\hline \multicolumn{7}{|c|}{ Very preterm $(28+0-31+6)$} \\
\hline SCUH & $6 / 1095(0.55)$ & $2 / 547(0.37)$ & $>0.99$ & $3 / 1130(0.27)$ & $1 / 524(0.19)$ & $>0.99$ \\
\hline QLD & $163 / 20939(0.78)$ & 79/10154 (0.78) & $>0.99$ & $191 / 20438(0.93)$ & $77 / 10162(0.76)$ & 0.12 \\
\hline \multicolumn{7}{|c|}{ Moderate/late preterm $(32+0-36+6)$} \\
\hline SCUH & $82 / 1095(7.49)$ & $25 / 547(4.57)$ & 0.034 & $72 / 1130(6.37)$ & $20 / 524(3.82)$ & 0.045 \\
\hline QLD & $1515 / 20939(7.24)$ & $678 / 10154(6.68)$ & 0.09 & $1508 / 20438(7.38)$ & $757 / 10162(7.45)$ & 0.84 \\
\hline
\end{tabular}

TSCUH: Sunshine Coast University Hospital

${ }^{\ddagger}$ QLD: State of Queensland, Australia

Bold indicates significance of $P$ value $<0.05$

Table 2. Perinatal characteristics at the Sunshine Coast University Hospital from 2018-2020.

\begin{tabular}{|c|c|c|c|c|c|c|}
\hline $\begin{array}{l}\text { Characteristic } \\
\text { No./Total No. (\%) }\end{array}$ & $\begin{array}{l}\text { No lockdown } \\
\text { Apr-May 2018-9 }\end{array}$ & $\begin{array}{l}\text { Lockdown } \\
\text { Apr-May } 2020\end{array}$ & $P$ & $\begin{array}{l}\text { No lockdown } \\
\text { Jun-Jul 2018-9 }\end{array}$ & $\begin{array}{l}\text { Post-lockdown } \\
\text { Jun-Jul } 2020\end{array}$ & $P$ \\
\hline Maternal age ${ }^{\S}$ (median, IQR) & $31(27-34)$ & $30(26.5-34)$ & $>0.99$ & $30(26-34)$ & $31(27-34)$ & 0.78 \\
\hline Age under 20 years & $23 / 1095(2.10)$ & $8 / 547(1.46)$ & 0.40 & $15 / 1130(1.33)$ & $4 / 524(0.76)$ & 0.46 \\
\hline Age 20 to 40 years & $1045 / 1095(95.43)$ & $527 / 547(96.35)$ & 0.90 & $1078 / 1130(95.40)$ & $505 / 524(96.38)$ & 0.89 \\
\hline Age over 40 years & $27 / 1095(2.47)$ & $12 / 547(2.19)$ & 0.74 & $37 / 1130(3.27)$ & $15 / 524(2.86)$ & 0.67 \\
\hline Body Mass Index ${ }^{\S}$ (median, IQR) & $27(24-58)$ & $29(25-54)$ & $<0.01$ & $28(24-60)$ & $29(25-58)$ & 0.030 \\
\hline Underweight $(<18)$ & $30 / 1095(2.74)$ & $10 / 547(1.83)$ & 0.27 & $25 / 1130(2.21)$ & $3 / 524(0.57)$ & 0.022 \\
\hline Healthy weight (18-25) & $603 / 1095(55.07)$ & $234 / 547(42.78)$ & $<0.01$ & $570 / 1130(50.45)$ & $242 / 524(46.18)$ & 0.34 \\
\hline Overweight (25-30) & 296/1095 (27.03) & $165 / 547(30.16)$ & 0.32 & $304 / 1130(26.90)$ & $150 / 524(28.63)$ & 0.58 \\
\hline Obese $(>30)$ & $142 / 1095$ (12.97) & $113 / 547(20.66)$ & $<0.01$ & $194 / 1130(17.17)$ & $98 / 524(18.70)$ & 0.52 \\
\hline Unknown & 24/1095 (2.19) & $25 / 547(4.57)$ & $<0.01$ & $37 / 1130(3.27)$ & $31 / 524(5.92)$ & 0.016 \\
\hline \multicolumn{7}{|l|}{ Parity } \\
\hline Nulliparous & $425 / 1095$ (38.81) & $218 / 547$ (39.85) & 0.79 & 448/1130 (39.64) & $202 / 524(38.55)$ & 0.78 \\
\hline Primiparous & $384 / 1095(35.07)$ & $190 / 547(34.74)$ & 0.93 & $375 / 1130(33.19)$ & 183/524 (34.92) & 0.63 \\
\hline Multiparous & 286/1095 (26.12) & $139 / 547(25.41)$ & 0.81 & $307 / 1130(27.17)$ & $139 / 524(26.53)$ & 0.84 \\
\hline \multicolumn{7}{|l|}{ Mode of delivery } \\
\hline Spontaneous vaginal birth & $661 / 1095(60.37)$ & $318 / 547(58.14)$ & 0.66 & $651 / 1130(57.61)$ & 278/524 (53.05) & 0.35 \\
\hline Vacuum-assisted birth & $96 / 1095(8.77)$ & $68 / 547(12.43)$ & 0.036 & $143 / 1130(12.65)$ & $69 / 524(13.17)$ & 0.80 \\
\hline Forceps-assisted birth & $19 / 1095(1.74)$ & $14 / 547(2.56)$ & 0.27 & $23 / 1130(2.04)$ & $16 / 524(3.05)$ & 0.22 \\
\hline Vacuum + forceps-assisted birth & $1 / 1095(0.09)$ & $0 / 547(0.00)$ & $>0.99$ & $1 / 1130(0.09)$ & $0 / 524(0.00)$ & $>0.99$ \\
\hline Elective caesarean & $125 / 1095(11.41)$ & $79 / 547(14.44)$ & 0.12 & $136 / 1130(12.04)$ & $72 / 524(13.74)$ & 0.39 \\
\hline Emergency caesarean (in labour) & $156 / 1095(14.24)$ & $55 / 547(10.05)$ & 0.034 & $152 / 1130(13.45)$ & $79 / 524(15.08)$ & 0.44 \\
\hline Emergency caesarean (no labour) & $37 / 1095$ (3.38) & $13 / 547(2.38)$ & 0.28 & $24 / 1130(2.12)$ & $10 / 524(1.91)$ & 0.78 \\
\hline
\end{tabular}

$\S \mathrm{P}$ values calculated with the Mann-Whitney $\mathrm{U}$ test. Unmarked $\mathrm{P}$ values calculated using Chi-squared or Fisher's exact test, where appropriate.

Bold indicates significance of $P$ value $<0.05$ 
medRxiv preprint doi: https://doi.org/10.1101/2021.08.06.21261711; this version posted August 7, 2021. The copyright holder for this preprint (which was not certified by peer review) is the author/funder, who has granted medRxiv a license to display the preprint in perpetuity.

All rights reserved. No reuse allowed without permission.

Table 3. Birth outcomes and proposed aetiologies for preterm birth during the lockdown and post-

lockdown periods from 2018-2020 at the Sunshine Coast University Hospital.

\begin{tabular}{|c|c|c|c|c|c|c|}
\hline $\begin{array}{l}\text { Birth outcome } \\
\text { No./Total No. (\%) }\end{array}$ & $\begin{array}{l}\text { No lockdown } \\
\text { Apr-May 2018-9 }\end{array}$ & $\begin{array}{l}\text { Lockdown } \\
\text { Apr-May } 2020\end{array}$ & $\boldsymbol{P}$ & $\begin{array}{l}\text { No lockdown } \\
\text { Jun-Jul 2018-9 }\end{array}$ & $\begin{array}{l}\text { Post-lockdown } \\
\text { Jun-Jul } 2020\end{array}$ & $\boldsymbol{P}$ \\
\hline Spontaneous live preterm birth & $52 / 100(52.00)$ & $16 / 30(53.33)$ & 0.94 & $50 / 80(62.50)$ & $11 / 26(42.31)$ & 0.33 \\
\hline Preterm premature rupture of membranes & $26 / 100(50.00)$ & $8 / 30(26.67)$ & 0.96 & $28 / 80(35.00)$ & $7 / 26(26.92)$ & 0.58 \\
\hline Preterm labour and birth & $16 / 100(30.77)$ & $6 / 30(20.00)$ & 0.67 & $18 / 80(22.50)$ & $4 / 26(15.38)$ & 0.78 \\
\hline Multiple pregnancy & $10 / 100(19.23)$ & $2 / 30(6.67)$ & $>0.99$ & $4 / 80(5.00)$ & $0 / 26(0.00)$ & 0.57 \\
\hline latrogenic live preterm birth & $39 / 100(39.00)$ & $11 / 30(36.67)$ & 0.88 & $24 / 80(30.00)$ & $8 / 26(30.77)$ & 0.96 \\
\hline Intrauterine growth restriction & $10 / 100(10.00)$ & $3 / 30(10.00)$ & $>0.99$ & $4 / 80(5.00)$ & $1 / 26(3.85)$ & $>0.99$ \\
\hline Hypertension & $8 / 100(8.00)$ & $2 / 30(6.67)$ & $>0.99$ & $5 / 80(6.25)$ & $2 / 26(7.69)$ & $>0.99$ \\
\hline Multiple pregnancy & $17 / 100(17.00)$ & 4/30 (13.33) & 0.79 & $10 / 80(12.50)$ & $4 / 26(15.38)$ & 0.75 \\
\hline Other maternal comorbidities & $2 / 100(2.00)$ & $1 / 30(3.33)$ & 0.55 & $2 / 80(2.50)$ & $1 / 26(3.85)$ & $>0.99$ \\
\hline Fetal distress & $1 / 100(1.00)$ & $1 / 30(3.33)$ & 0.42 & $2 / 80(2.50)$ & $0 / 26(0.00)$ & $>0.99$ \\
\hline $\begin{array}{l}\text { Placental abruption or } \\
\text { antepartum haemorrhage }\end{array}$ & $1 / 100(1.00)$ & $0 / 30(0.00)$ & $>0.99$ & $1 / 80(1.25)$ & $0 / 26(0.00)$ & $>0.99$ \\
\hline Stillbirth $\geq 20$ weeks & $2 / 100(2.00)$ & $3 / 30(10.00)$ & 0.09 & $3 / 80(3.75)$ & $4 / 26(15.38)$ & 0.08 \\
\hline Termination $\geq 20$ weeks & $7 / 100(7.00)$ & $0 / 30(0.00)$ & 0.35 & $3 / 80(3.75)$ & $3 / 26(11.54)$ & 0.18 \\
\hline
\end{tabular}

Bold indicates significance of $\mathrm{P}$ value $<0.05$

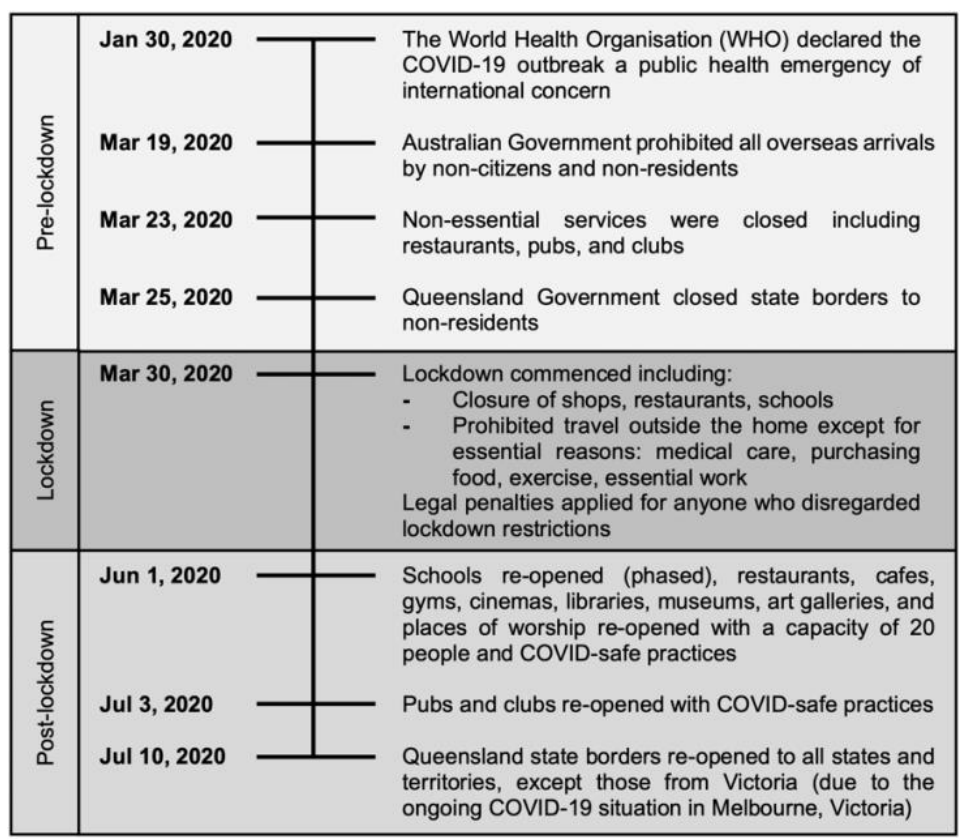

Figure 1. Timeline of COVID-19 restriction implementation in Queensland, Australia.[4,5] 